\title{
Educational Studies and Teacher Education in Ireland, 1965-1995
}

\section{John Coolahan}

To cite this article: John Coolahan (1998) Educational Studies and Teacher Education in Ireland, 1965-1995, Paedagogica Historica, 34:sup1, 431-446, DOI: 10.1080/00309230.1998.11434896

To link to this article: https://doi.org/10.1080/00309230.1998.11434896

册 Published online: 20 May 2015.

Submit your article to this journal $[\pi$

Џ Article views: 55

4 Citing articles: 1 View citing articles 지 


\title{
EDUCATIONAL STUDIES AND TEACHER EDUCATION IN IRELAND, 1965-1995
}

\author{
John Coolahan \\ National University of Ireland, Maynooth/Kildare
}

As in some other countries, the history of Educational Studies in Ireland reveals a rather chequered pattern. Periods of breakthrough, promise and serious concern for their promotion have sometimes been succeeded by periods when the approach to the subject was unimaginative, instrumental and intellectually shallow. ${ }^{1}$ In Ireland the early part of the century was one of promise and achievement regarding Educational Studies, but it was succeeded by a more mundane, unimaginative epoch. The period since the mid-sixties has recorded many striking achievements in rebuilding Educational Studies in general, and in their relationship with teacher education; but it has also been an era of challenge to Educational Studies. This paper seeks to trace and analyse the progress made and how challenges have been met.

\section{A DECADE OF RENEWAL AND REFORM, 1965-1975}

Educational Studies had reached a very weak position by the early nineteen sixties, just at the time that there was to be a great renewal and development of the Irish education system generally, including a massive expansion in post-primary school enrolment. ${ }^{2}$ Education departments in teacher training colleges and in universities were poorly positioned to cope with a rapidly changing education scene, or to provide the leadership or research input to help shape reform measures. 
Several major reports were published on Irish education in the sixties which had implications for Educational Studies and teacher training. One of these was the Investment in Education Report, published in 1965. This was conducted in the context of an OECD review of Irish education initiated in 1962. From a close scrutiny of the supply and demand pattern, the Report demonstrated that an increased output of teachers would be required at all levels and urged a redeployment of teaching resources to secure a more satisfactory and economic return from the teaching force. The Report of the Commission on Higher Education (1967) had more specific proposals to make regarding Education and teacher training. It urged a restructuring of the teacher training colleges and an extension of their courses from two to three years. However, the Report took most direct issue with prevailing trends when it objected to the neglect of Educational Studies by the universities. It stated unequivocally:

In our opinion, the study of education should not be regarded as the "poor relation" of university studies. It should be given equal importance with other studies. It would be wrong to conceive of the function of university departments of education simply as departments for the training of teachers in pedagogics. Education, with all its philosophical, historical, economic and sociological implications, forms a field of study that requires to be pursued and investigated no less than other university subjects; ... 3

The Report also deprecated the lack of educational research, remarking:

Paucity of research into educational problems in this country has been disclosed by the evidence. So far as we can ascertain, educational research is neither well organised nor well supported. ${ }^{4}$

Such statements were an authoritative indictment of the state of affairs which had come to exist. The Report urged "that the university departments of education should all be staffed and maintained at a level and to an extent appropriate to a major university department." 5

While full-scale remedial measures were slow to emerge, some changes were already taking place which gradually, and on accumulation, would change significantly the overall situation for Education. Shaped by historical conflict in the nineteenth century, the training colleges were all denominational. Four of them were situated in Dublin. There were two large Catholic Colleges - St. Patrick's, Drumcondra and Our Lady of Mercy, Carysfort, Blackrock - as well as a smaller college at Marino, also in Dublin, conducted by the Christian Brothers Congregation. A small Church of Ireland College was located at Rathmines, Dublin. Another large Catholic College, Mary Immaculate College, was situated in Limerick, in the South West of the country. Beginning from the mid sixties, the 
training colleges benefited from new extensions and larger intakes of students. The increase in student numbers was linked to a rising population in the schools and to efforts to improve pupil/teacher ratios. The colleges became more regularly known as Colleges of Education and became more "open" as institutions, with more personal responsibility devolving on students in the management of their scholastic and leisure time. The single sex college gradually gave way to mixed colleges, with female students coming to form the majority of the student body. The student body became more diversified by a greater infusion of university graduates on a one year training course and the participation of what were known as "mature" students within the student body. Entry for the great majority of students was based on their performance in the terminal secondary school examination, the Leaving Certificate. In line with the traditional high regard for the career of teaching, entry was very competitive and a place in a college of education was highly prized. The entrants came from the top quartile of the performers in the Leaving Certificate Examination and came predominantly from non-urban backgrounds. Over subsequent years the tradition of a place in a college of education continued to be similarly competitive, but more attractive to young women than to men and the geographical origin of students became more varied with a greater mix from urban backgrounds. This latter development was welcomed to help bridge a culture gap between teachers of rural background and pupils from inner city environments.

From 1962 the colleges assumed greater academic responsibility for their courses and examinations and were less under the control of the state Department of Education. An important change occurred in 1963 when, following discussions between College of Education and Department of Education personnel, new courses were devised which reduced the range of subjects to be studied and established a restructured course in Education. As well as re-vamped courses in Methods and Principles of Education, this now included Psychology and elective courses such as History of Education, Sociology of Education and Comparative Education. The change was directed at giving a more theoretical underpinning to the students' studies. The staffs in the Education Departments were greatly expanded allowing much more scope for specialisation.

On the grounds of St. Patrick's College of Education in Drumcondra, Dublin, the Educational Research Centre was established in 1966. The establishment of the Educational Research Centre was symbolic of a new concern that the health and vitality of a modern education system were closely connected with empirical research on the system. Since its establishment the Centre has carried out a wide range of research, and, while acting as an independent agency, the Centre has been a yeasting influ- 
ence among college staffs and some teachers. Dr. Tom Kellaghan, the Centre's first Director, highlighted the contemporary crossroads at which teacher education then was:

The teacher's role today is at a point of decision. On that decision will depend whether the technical or professional aspect of his job prevails. The pressures for development in both directions are great.

He urged more attention to the professional development aspect and also encouraged the universities to give greater attention to Educational Studies and Research. ${ }^{6}$

Meanwhile the understaffed Education Departments of the universities were being stretched to breaking point as student numbers more than quadrupled within the decade 1959-1969 in line with a fast expanding post-primary system. The predicament of Education in the universities reached its nadir in the mid-sixties in terms of insufficient staff, resources and funding. Heed was taken, however, of the calls of the Commission on Higher Education that the university departments should be expanded as a matter of urgency and that a more active research role be developed. Recruitment of more full-time staff with various specialisms took place. Premises and facilities were also improved, particularly in the areas of audio-visual equipment, resource rooms, micro-teaching studios, workshop spaces and library resources.

The teacher education courses were restructured, the foundation areas of Philosophy, History, Psychology, Sociology and Curriculum were redevised and were supplemented with educational technology, pedagogics etc. Greater efforts were made to give an applied dimension to Educational Studies and to foster more student engagement through seminars, tutorials and workshops. All Education departments revitalised their postgraduate work since 1970. M.Ed. courses were established in all universities and M.A. degrees in Education, and Ph.D's in Education were extended. The greater availability of post-graduate degrees in Educational Studies, with flexible formats to match student requirements, has allowed scope for much-needed specialisation of an advanced character to meet the needs for expertise and skill within the education system.

There was a great increase in postgraduate diplomas of a specialist character. These included diplomas in Career Guidance, in Special Education, in the Education of the Deaf, in Remedial Education, in Computers for Education in Curriculum Development, in Catechetics, in Compensatory and Remedial Education. Courses in areas such as Educational Management and Pastoral Care were set up at a later stage. All these inservice diplomas had an underpinning in Educational Studies. 
The Higher Education Authority (HEA) published a Report on Teacher Education in 1970 which again gave significant endorsement to Educational Studies and their role in teacher education. ${ }^{7}$ It urged the extension of the course for primary school teachers to three years. This coincided with a major push by the presidents of the colleges of education and of the strong primary school teachers' union, the Irish National Teachers' Organisation (I.N.T.O), for the award of university degrees to primary teachers. This was a status issue which had exercised these agencies in intensive lobbying. Eventually, in 1973, the Minister for Education, Mr. Richard Burke, supported this demand and requested the universities to investigate the possibility of granting university degrees to primary teachers on a course of study extended to three years. The universities responded favourably to the Minister's request. Working groups were established between the universities and the colleges to plan the way forward.

It should be pointed out that this move to university status for primary teachers formed part of a broader governmental strategy on teachers' salaries and the teaching profession at that time. By 1972 the government had achieved its aim of establishing a common salary scale for all teachers, with extra allowances for qualifications and levels of special responsibilities. Also, in 1970, the government established a new college, Thomond College, which was to serve for the education and training of physical education, woodwork, metalwork and rural science teachers. These were to participate in a four year concurrent degree course, the degrees being awarded by the recently established National Council for Educational Awards (NCEA). Art teachers were also to follow a four year course leading to an NCEA degree. Interestingly, the degree for Home Economics teachers was to be awarded by universities. As part of the upgrading of the courses for the various categories of teachers there was a greater input of Educational Studies, taught at degree level.

Within the broad strategy for an all graduate teaching profession in the early seventies, arrangements for awarding degrees for primary teachers were concluded quickly, with very little tension or disagreement between the involved parties. The new professional degree for primary teachers, the B.Ed., was inaugurated in the academic year of 1974. The three largest colleges became "Recognised Colleges" of the federal National University of Ireland. The arrangement was an interesting one which allowed maximum freedom to the colleges to conduct their own affairs and lifestyles. The links with the university were based solely on academic matters. College of Education staff who were appropriately qualified were "recognised" staff by the university. University representatives sat on interview boards for new appointees, courses were submitted for approval 
by the university, as were marks and standards, and university staff acted as external examiners on examination scripts and teaching practice. The students did not attend the university for any courses. The university required certain standards in the colleges' library holdings. Three smaller colleges became associated with the University of Dublin (Trinity College). The involvement of the university in the life of these colleges tended to be closer, the framework of studies rather different and students attended at the university for some lectures. ${ }^{8}$

The arrangements arrived at by the mid seventies between the colleges and the universities worked well and very little change was made in subsequent years until 1991, when the government decided that St. Patrick's College in Dublin and Mary Immaculate College in Limerick should be disconnected from their association with the National University of Ireland and link up with two universities recently re-organised by the government. This was not due to any dissatisfaction or disagreement about the original arrangement, but was linked more to the geographical proximity of St. Patrick's with the new City of Dublin University and of Mary Immaculate with the new University of Limerick. The colleges of education could also give a more arts dimension to the new universities and could diversify more. Thomomd College (set up in 1970) was also absorbed in the University of Limerick in the early nineties.

The H.E.A. Report of 1970 also strongly supported the more structured provision of inservice education courses for teachers. This signalled a new emphasis of thinking on teacher education which was to become stronger in subsequent years. The call in 1970 coincided with a period of significant curricular reform in the schools. All the courses for the Intermediate Certificate Examination (taken at about age 15/16) were reformed in the mid-sixties and the courses for the Leaving Certificate Examination (taken at age 17/18) were reformed in the late sixties. A major reform of the primary school curriculum involving a much more childcentered focus, an expansion of the subject range and more active styles of pedagogy, also took place at this time and became fully operational in 1971. In the early seventies the provision of inservice education of teachers improved and was largely related to promoting the implementation of the curricular reforms. A significant initiative in this regard was the establishment of twenty regional Teacher Centres in 1972. Teacher involvement in this inservice work was also reflected in the setting up of the Irish Association for Curriculum Development in 1971 and the more active role taken by various subject associations, which were associations of teachers who specialised in curricular subjects in post-primary education. Personnel from the universities and colleges of education participated in the inservice education initiatives in those years. However, the oil crisis of 
1973-74 had a significant, deleterious effect on this burgeoning inservice activity. Cutbacks in available expenditure took place and a slowing down occurred in the momentum which had been gathering for inservice education. It was never to cease altogether, but a structured coordinated system of inservice education failed to materialise in those years.

It was also significant that the H.E.A. Report on Teacher Eduction, in 1970, emphasised the need for more investment in and attention to research in education. Furthermore, it took the view that Educational Studies and teacher education were so important that a permanent body should be instituted to deal with relevant matters on a developmental basis. A Ministerial Committee was established to investigate what type of body would be most appropriate and it reported in 1974 in favour of establishing a Teachers' Council with wide-ranging advisory, executive and administrative powers. Primarily, it would be a self-regulatory body for the teaching profession, on the lines of the medical and law councils. It would approve teacher education courses, promote educational research and act as a registration body for the profession. Teachers would form a majority on the proposed Council for which an elaborate organisational structure was proposed. ${ }^{9}$ This was a strategically important proposal for the teaching profession. The only other country with a similar teachers' council was Scotland. If established, it would have symbolised a major landmark in the development of the teaching profession. However, one of the teacher unions was in opposition to it, objecting to the disciplinary, self regulatory powers proposed. The proposal also coincided with a period of economic retrenchment in public expenditure. Furthermore, there were some personnel in the Ministry who did not relish the independent powers which might be exercised by such a council. In the event, the proposed Teachers' Council was not established, but the idea did not disappear, and it resurfaced seriously as a policy issue in the 1990s. A relevant initiative which did take place in 1975 was the establishment of the Educational Studies Association of Ireland (ESAI). This was an organisation which brought together personnel in education departments, teachers and others with a research interest in Educational Studies. The ESAI has continued to provide a valuable forum through annual and other conferences for multidisciplinary research on educational issues. It publishes Irish Educational Studies on an annual basis and also publications on specific themes. It provides a useful annual register for research students on postgraduate educational research carried out in Irish universities.

Overall, when surveying the decade from 1965 to 1975 one could say that there had been a virtual revolution in the place and status of educational studies in Ireland. All education departments and teacher education institutions had been greatly altered. Teacher education courses had 
been reformed. An all-graduate teaching profession was in place, which enjoyed a common salary scale, with allowances for extra qualifications. Social confidence in the teaching profession almost led to the establishment of a Teachers' Council. Educational research became greatly vitalised, linked to the expansion of post-graduate education studies. There was a huge expansion in post-graduate theses, while across the whole spectrum of research methodology research expanded greatly, but with limited public funding. There was also great vitality in the number of bodies and associations which have been involved in promoting educational debate, conferences and workshops. Publications of various kinds by such agencies have provided a good range of outlets for articles and research findings in Education. Significant international linkages were forged by the educational research community. For instance, Irish personnel have played a very active role within the Association for Teacher Education in Europe (ATEE).

\section{A PERIOD OF BUFFETING AND DIFFICULTY, 1976-1991}

In Ireland, as in many other countries, the educational reforms of the sixties and early seventies benefitted from the generally buoyant economic circumstances and the public confidence about investment in education. However, the golden age was not to last. From the mid-seventies a changed cycle of circumstances came into operation. Education generally, as well as teacher education, experienced difficult and buffeting times. The demographic decline in most European countries had varied consequences for teacher education institutions including closure, amalgamation, staff redundancies, declining morale. Allied to the demographic decline was the serious economic recession of the period. Cut-backs in educational expenditure led to disimprovements in pupil-teacher ratios and support services for schools and to difficulties for teacher salaries. Something of "a morning after optimism" effect set in as societies witnessed the re-emergence of low or zero growth economies, recession, high unemployment and social problems arising from complex changes in society. The early optimism and unreal expectations of education as the key to a brave new world were replaced by a lack of confidence in education and an astringent critique of schooling from a wide spectrum of ideological positions. 10

In Ireland while some consolidation of Educational Studies took place, the momentum of development slowed. The national economic problems became very intensified in the last seventies and early eighties. Despite the presence of a reforming Minister for Education in the early eighties 
and the publication of a number of reports on improving aspects of the education system, the crisis in the public finances undermined movement forward. A striking instance of this was the failure by the government to respond in any way to the report of a ministerial committee on inservice education, published in 1984. This Report was a major review of existing provision, offered a key analysis of the need for greater inservice education and recommended many measures for action. The Report also considered that the situation warranted the establishment of a National Council for the inservice education of teachers, supplemented by local councils. ${ }^{11}$ The lack of any political action on this report was symptomatic of the changed times.

The teaching profession was also greatly annoyed in the mid-eighties by cutbacks in educational services and by governmental refusal to honour a salary award decided by the Salary Arbitration Board. Tension grew very high between the teacher unions and the Department of Education, culminating in strikes and mass public demonstrations by teachers. Neither were Irish public attitudes unaffected by developments in other countries, particularly in Ireland's nearest neighbour, Britain. There, significant changes in policy were occurring which were very inimical towards Educational Studies and sought a shift back to a more apprenticeship style of teacher education. ${ }^{12}$ Allied to ideological motives many policy initiatives were taken, betokening a lack of confidence in the educational professionals involved in Educational Studies. One of the key concerns which faced Irish educationalists was, would Ireland go down that same road and would the gains made in the 1965-75 era be scuppered in the process? Educational Studies was again at a turning point - would policy veer back to the technician model or continue to support the teacher as professional concept?

For a while the signs were not good. Influenced by a decline in the annual birthrate, which set in by 1980 , the Government abruptly decided to close the country's largest college of education, Our Lady of Mercy College, Carysfort, Dublin, in 1987. Despite great public opposition, the college was closed and left a legacy of bitterness as well as evidence of maladroit administration. Subsequently, the Government invited the OECD to review Irish education with particular reference to teacher education and the teaching profession. This gave rise to some apprehension about the Government's timing and intentions. Before the OECD Report was published, the Government, in January 1991, announced a decision to close three of the five university education departments. This tended to confirm inimical intentions, and the terms of the announcement betrayed a very impoverished view by the Government of the contemporary work of education departments. Links were not close between the education de- 
partments and senior staff in the Ministry, who were out of touch with many of the developments which had been taking place within the departments. They tended to see the departments in their older traditional role of being mainly preoccupied with pre-service teacher education, which was no longer the case. The Department of Finance applied pressure, as it had done in the case of the Carysfort College in 1987, carrying forward a simple logic which stated that if pupil numbers were in decline, then a follow-on effect should be a cutback in the supply of secondary teachers also as the pupil cohort moved through the system. The Department of Education was poorly positioned to defend the case of the education departments and so a Cabinet decision to close three of the five departments came to pass.

\section{RE-APPRAISAL AND POLICY DEVELOPMENT, 1991-1996}

The Professors of Education had a tradition of close cooperation on professional issues and they opposed the government decision with early detailed responses as to the real situation and the consequences if the decision was implemented. They successfully recruited the direct support of the Presidents of all the involved universities. They also elicited the support of the teacher unions and the management bodies of the schools. It was clear to all that what was at stake was of vital importance if Educational Studies were to be maintained and developed in later years.

The timing and nature of the independent OECD Report, published in 1991, were of significance in the debate. The OECD Review team, which had visited all the departments and otherwise investigated many features of the Irish education system, came up with a very different analysis to that of the Irish government, which had made its decision without making any such investigative visits. The OECD presented a very positive view of the work of education departments, of the conduct of Educational Studies and of the potential for and need of further development. Among other endorsements, it stated:

We visited nearly all the initial education institutions and were impressed with the quality and commitment of their staffs, the strength of the programmes and the standard of buildings, teaching spaces, laboratories, equipment and other facilities generally available ... Most important, the quality of the teacher educators is high ... Thus, a well organised, effective and professionally and academically sound structure for initial teacher education already exists ... There have been many quite substantial improvements in the curriculum of teacher education and these have generally been achieved by thorough going appraisals. ${ }^{13}$ 
The Report went on to stress the importance of regarding induction and inservice teacher education as integral parts of teacher formation as well as initial teacher education:

We believe that the best returns from further investment in teacher education will come from the careful planning and construction of a nationwide induction and inservice system using the concept of the teaching career as the foundation. ${ }^{14}$

It went on to add:

The existing training institutions are potentially the only sure guarantee of a high quality system of inservice training ... In our view, much of their attention and a substantial portion of their resources should be redirected to that end. How this is accomplished is critical for the future well-being of Irish education. If it is treated as an expedient to minimise the downturn in initial teacher training programmes, the nation, and, eventually, the very programmes themselves will be the losers ... Finally, preservice and inservice teacher training programmes are essential components of professional institutions that have responsibility for research and community activities. ${ }^{15}$

Such authoritative comments were to be influential and, when combined with representations of significant interests in the Irish context, they would help to protect the cause of Educational Studies within the universities. In the event, The Government did not proceed with its decision to close departments, but did impose quotas on the numbers of applicants who could be taken on the preservice secondary teacher education programmes. In June 1992, the Government published its Green Paper: Education For $A$ Changing World. The chapter dealing with the teaching profession paid tribute to its quality, adopted the OECD approach of combining initial, induction and inservice teacher education as the guiding approach in policy, and, in general, endorsed Educational Studies and teacher education. It also resurrected the proposal to establish a self-governing Teachers' Council. ${ }^{16}$ Thus, it seemed that the policy was not going the way of British policy, and was following the professional way forward. The Green Paper did propose that it might be best if the recurrent B.Ed. degree approach for primary teacher education were dropped in favour of adopting the consecutive model. However, there was no support for such a change and the proposal has been dropped. A commitment to greatly expanded and varied inservice education for teachers was clearly in evidence.

It was also interesting that in the preparation of the Green Paper the Ministers for Education involved sought close assistance from the staff of a university education department. This became more so the case of the National Education Convention which was a centrepiece of an unprecedented and wide-ranging consultative process on the Green Paper. The 
National Convention took place over two weeks and involved sustained multi-lateral dialogue and analysis by forty two organisations and the Department of Education, under the direction of an independent academic secretariat. The Secretary General of the Convention was a university professor of education and he was given the freedom to choose an independent secretariat. He chose a team of six academics from the field of Educational Studies, as well as three leading educational academics from outside the country. This vote of confidence by the Minister in educational academics was further emphasised when the top management team of the Department of Education also agreed to be questioned by the Secretariat in public forum, with television cameras present. The Report On The National Education Convention strongly endorsed the professional approach whereby Educational Studies would continue to inform all stages of teacher education. The Report stated:

There was wide support for the policy proposal of the Green Paper which viewed the teaching career as a continuum involving initial teacher education, induction processes and in-career development opportunities available periodically throughout a teacher's career. ${ }^{17}$

The Report spelled out a range of developmental initiatives for teacher education and Educational Studies. The Report also supported the establishment of a Teachers' Council and outlined some of its desirable functions:

Its powers might include establishing a register for all teachers, laying down the conditions for registration, administering disciplinary procedures, assisting in induction processes, offering advice on a wide range of policy matters relating to teacher-supply and demand, preservice training, inservice training and other forms of professional development. It might also propose or commission educational research studies on teaching issues. Such a Teaching Council could do much to promote a distinguished future for the teaching profession in Ireland into the new century. ${ }^{18}$

The Minister for Education published the Government's White Paper: Charting Our Education Future, in April 1995. It built on the large degree of consensus which had been achieved at the National Education Convention. It carried forward the high regard for the teaching profession and teacher education contained in the reports alluded to above. It indicated that a review would be undertaken of the course for secondary teacher education and the guidelines proposed are very much in line with what universities favour, including:

the development of a firm understanding of the foundation disciplines of modern educational theory and practice which would equip student teachers for successful careers in a changing environment. ${ }^{19}$ 
The White Paper contained a thorough approach to induction and inservice teacher education. It clearly endorsed a " 3 I's" policy of initial, induction and inservice approach to the career of teaching. Its policy statements on inservice teacher education now carried credibility because they were part of a strategic investment of $£ 40$ million over a five year period for inservice education. The content and tone of the White Paper of 1995 were in striking contrast to the climate of thought which, in January 1991, had been reflected in a governmental decision to close down three of five university education departments. The wide consultative debate which took place nationally from the publication of the OECD Report in June 1991, and, more particularly, since the Green Paper of June 1992, had greatly altered perspectives. The professional education community took the opportunity of participating fully in this debate and were in a position to influence policy outcomes. These outcomes have helped to foster a solidarity and unity of purpose between the involved sectors which promises well for the future. An alternative malign scenario of slippage, decline and loss regarding Educational Studies and teacher education could also have occurred. In this context, it might also be useful to note that in 1991 the university Professors of Education set up a Standing Committee with the teacher unions on areas of common interest. This has served to improve communication, to clarify problems and to promote worthwhile developments. The Standing Committee has convened a number of seminars on the inservice education of teachers, on teaching as a profession and on teacher induction and has published reports thereon. ${ }^{20}$

The White Paper endorsed the proposal to establish a Teachers' Council and stated that, following consultation, "the Minister will publish a draft legislative framework for the operation of the Council... ${ }^{21}$ The Paper went on to set out an outline of the remit and composition of a Teachers' Council, the specific detail of which is to be set out in the legislative proposals. Thus, the establishment of a teachers' Council has moved forward to being declared government policy and when established will be a landmark in the evolution of the teaching profession in Ireland. Significantly also, the White Paper emphasised the significance of educational research for public policy stating:

Research can be a potent agent of change. It provides a basis for questioning assumptions, problem identification, the evaluation of alternatives and the assessment of the outcomes ... educational research sustains the beneficial aspects of the system while, at the same time, stimulating creativity and development. ${ }^{22}$

The government signalled its intention of linking closely with the educational research community, stating as a principle of policy: 
The development and promotion of close linkages between educational research agencies and the Department, with the objective of ensuring that policy issues are supported by relevant research. 22

This is very much in line with the policy of agencies such as the Educational Studies Association of Ireland, and is in keeping with international concerns in this field. ${ }^{23}$

Thus, the indications are that Educational Studies and their input to teacher education at all stages, as well as their contribution to research knowledge, operating in a climate of respect for the teaching profession seem secure, and poised for further development. The dangers to the position of Educational Studies seem to have been withstood and a healthy mutual understanding established between politicians and educationalists. This is of importance to society.

A criterion of professionalism in education is the command over, and skill in the application of a body of specialised and systematised knowledge to help the teacher become a "reflective practitioner." 24 The manner of the organisation of, and initiation into the knowledge and skills evolves in the light of experience, insight and further research. The content and teaching of Education need to be of a quality to provide a secure basis from which professional development may grow and be fostered giving assurance, competence and sense of direction to practitioners. What the overall study of Education in a professional programme should do is to equip the educator with classroom skills, deepen his/her understanding, widen the area of knowledge reference, and motivate the teacher to act in an intelligent, artistic and developmental manner. However, there is also a challenge to Educational Studies to ensure that they reflect a coherence and a relevant purpose with regard to teacher education. ${ }^{25}$ An awareness of the historical context and evolution of Educational Studies can serve as a significant bulwark against periodic utilitarian and instrumentalist attack. As Harry Broudy remarks:

Foundation Courses are not an intellectual luxury ... many of the problems of teaching are rooted in such contexts ... put into their appropriate contexts, many educational problems cease to be matters of technique. ${ }^{26}$

The value of foundation studies in Education is important for the individual and the community of educators:

Foundational knowledge not only provides the individual with empowering perspectives, but also makes possible a community of practitioners who share a fundamental set of interests in improving teaching. 27 
The comparative historical study of Educational Studies promoted by the ISCHE XVII Conference is very timely and could yield fruitful benefits for the well-being of Educational Studies and their role in teacher formation for a challenging future.

\section{REFERENCES}

1 COOLAHAN, John (1981). The Fortunes of Education as a Subject of Study and Research in Ireland. Irish Educational Studies Vol. 4, No.1, 1-34.

2 INSTITUTE OF PUBLIC ADMINISTRATION (1981). Irish Education, History and Structure. Dublin, 131-140.

3 COMMISSION ON HIGHER EDUCATION (1967). Report (Pr. 9389). Dublin: Stationery Office. Vol.1, 220, 211.

4 Ibid., 235.

5 Ibid., 221.

6 KELLAGHAN; Tom (1971). The University and Education. In: Academic Staff Association, U.C.D. (ed.). Contemporary Development in University Education, VI. Dublin: University College Dublin, 17-33.

7 HIGHER EDUCATION AUTHORITY (1970). Report on Teacher Education. Dublin: HEA.

8 COOLAHAN, John (1991). Teacher Education and the Universities: The Case of the Irish Republic. European Journal of Teacher Education, 14 (3), 287-296.

9 Report of Ministerial COMMITTEE ON A TEACHERS' COUNCIL (1974). (Department of Education, unpublished).

10 NEAVE, Guy (1987). Challenges Met: Trends in Teacher Education. Council of Europe. Newsletter 4/87.

11 Report of the COMMITTEE ON INSERVICE EDUCATION (1994). Dublin: Stationery Office, PL. 2216.

12 ALDRICH, Richard (1995, unpublished). Teacher Education in England and Wales Paper presented at the Winter University, Falun, Sweden. LAWTON, Denis (1991). The Future of Teacher Education in England and Wales. In John Coolahan (ed.). Teacher Education in the Nineties 1991, Vol.1, 181-190. Limerick: ATEE.

13 OECD (1991). Review of Irish Education. Paris: OECD, 97.

$14 \mathrm{lbid}, 98$.

15 Ibid, 88.

16 DEPARTMENT OF EDUCATION (1992). Green Paper: Education For A Changing World. Chap. 6, 161-170. Dublin: Stationery Office.

17 COOLAHAN, John (ed.) (1994). Report On The National Education Convention. Dublin: Stationery Office, 85

18 Ibid., 90

19 DEPARTMENT OF EDUCATION (1995). Charting Our Education Future. Dublin: Stationery Office, 124.

20 SWAN, Desmond (ed.). Teachers as Learners. SWAN, Desmond and Moira LEYDON (eds.). Teachers as Professionals. And SWAN, Desmond (ed.). Teacher induction. (in press)

21 White Paper, 135

22 Ibid., 199. 
23 COOLAHAN, John (1992). Synthesis Report. In Special Issue of the European Journal of Teacher Education: Educational Research and Teacher Education, Vol. 15, Nos.1-2, 80-84.

24 COOLAHAN, John (1993). Professionalism in Context. In D. Swan (ed.). Teachers as Professionals. Dublin, 7-16.

25 COOLAHAN, John (1991). Teacher Education in the Nineties: Towards A New Coherence. In John Coolahan (ed.). Teacher Education in the Nineties. (Association for Teacher Education in Europe), 1-28.

26 BROUDY, H.S. Variation in Search of a Theme. Journal of Educational Thought 19 (1), 37.

27 SOLTIS, J. F. A Reconceptualisation of Teacher Education. Teachers College Record 91 (3), 311-322. (Quoted by Andrew Burke [1992]. Teaching: Retrospect and Prospect. Oideas 39, 119.) 